\title{
TINJAUAN PENERAPAN ANALISA JABATAN DAN KOMUNIKASI ORGANISASI SEBAGAI PENGUKURAN MOTIVASI DAN DAMPAKNYA PADA KINERJA KARYAWAN BERDASARKAN PENDEKATAN SPSS VS LISREL
}

\author{
Antonius Nico Kristanto; Haryadi Sarjono \\ Jurusan Manajemen, Fakultas Ekonomi dan Bisnis, BINUS University \\ Jln. K.H. Syahdan No. 9, Palmerah, Jakarta Barat 11480
}

\begin{abstract}
PT Indo Nuansa Jaya is a chemical materials manufacturing company for oil drilling and drilling tools in Indonesia. The selling level of chemical materials for drilling in 2008 has reached to 348 units, in 2009 to 549 units, and in 2010 decreased to 447 units. The research method used is survey method; meanwhile the research type is associative. Data is gathered from questionnaire to employees. Data processing is using SPSS 16.0 and then compared to the result from data processing using LISREL 8.80. The research resulted that the analysis of duties has relation in 0,628 and has significant influence in $(0.516)^{2}=26.63 \%$ towards motivation. From the result, it could be founded that motivation could influence employees performance in $(0.412)^{2}$ or $16,97 \%$.
\end{abstract}

Keywords: post analysis, organization communication, motivation, employee performance

\begin{abstract}
ABSTRAK
PT Indo Nuansa Jaya merupakan perusahaan yang bergerak di bidang pengadaan bahan-bahan kimia untuk pengeboran minyak serta produk-produk alat pengeboran di Indonesia, yang tingkat penjualan bahan kimianya untuk pengeboran pada tahun 2008 memiliki tingkat penjualan mencapai 348 unit, di tahun 2009 meningkat mencapai 549 unit, dan di tahun 2010 mengalami menurun mencapai 447 unit. Metode yang digunakan dalam penelitian ini adalah metode survey, sedangkan jenis penelitian yang digunakan adalah asosiatif. Data diperoleh dari kuisioner yang dibagikan kepada karyawan perusahaan. Pengolahan data dilakukan dengan menggunakan SPSS 16.0 dan selanjutnya akan dibandingkan dengan hasil dari pengolahan data melalui LISREL 8.80. Hasil penelitian didapat bahwa analisa jabatan memiliki hubungan sebesar 0.628 dan memiliki pengaruh yang signifikan yaitu $(0.516)^{2}=26.63 \%$ terhadap motivasi. Dari hasil penelitian juga diketahui bahwa motivasi mempengaruhi kinerja karyawan sebesar $(0.412)^{2}$ atau sebesar $16.97 \%$.
\end{abstract}

Kata kunci: analisa jabatan, komunikasi organisasi, motivasi, kinerja karyawan

(*nama perusahaan disamarkan sesuai keinginan perusahaan) 


\section{PENDAHULUAN}

Mengelola sumber daya manusia di era globalisasi bukanlah hal yang mudah, setiap perusahaan dituntut untuk dapat mengelola usahanya dengan lebih baik lagi dengan kondisi yang stabil. Perusahaan dituntut untuk mampu mengelola kinerja karyawannya dengan sebaik mungkin. Hal ini dapat dilakukan dengan memotivasi karyawan untuk dapat bekerja lebih baik lagi. Selain Motivasi, Analisa Jabatan dan Komunikasi Organisasi juga dapat meningkatkan kinerja karyawan. Komunikasi Organisasi yang efektif akan membuat kinerja karyawan semakin baik, sedangkan saat komunikasi menjadi tidak jelas, hasilnya akan berdampak pada menurunnya kinerja karyawan.

Tabel 1 Tingkat Penjualan Perusahaan

\begin{tabular}{cccc}
\hline Tahun & $\mathbf{2 0 0 8}$ & $\mathbf{2 0 0 9}$ & $\mathbf{2 0 1 0}$ \\
\hline Penjualan & 348 & 549 & 447 \\
\hline
\end{tabular}

Sumber: Laporan Penjualan Perusahaan (2011)

Perusahaan memiliki catatan tingkat penjualan tiga tahun terakhir dengan peningkatan yang tidak signifikan yakni dari tahun 2008 ke tahun 2009 terdapat peningkatan penjualan sebanyak 201 unit, tetapi pada tahun 2009 ke tahun 2010, mengalami penurunan penjualan sebanyak 102 unit, data tersebut memberikan gambaran bahwa perusahaan harus melakukan perbaikan terhadap kinerja karyawan yang menurun. Hal ini yang melandasi penelitian tentang pengaruh analisa jabatan dan komunikasi organisasi terhadap motivasi dan dampak pada kinerja karyawan.

Hasil studi didapat, komunikasi memiliki peranan dalam keberhasilan perusahaan karena komunikasi dalam organisasi merupakan hal yang inti bagi suatu perusahaan, karena akan selalu berhubungan dengan kehidupan yang ada dalam perusahaan. Komunikasi organisasi merupakan arus informasi, pertukaran informasi, dan pemindahan arti di dalam suatu organisasi yang bersifat terbuka serta menerima energi dari lingkungannya dan mengubah energi ini menjadi produk atau servis dari sistem dan mengeluarkan produk atau servis ini kepada lngkungan (Katz dan Kahn dalam Muhammad, 2005).

Faktor lain adalah Analisa Jabatan berperan penting dalam meningkatkan kinerja karyawan, dimana saat karyawan mengetahui diskripsi yang jelas, analisa jabatan dapat membantu karyawan untuk mengetahui apakah tugas yang dilakukannya sudah sesuai, dan berusaha mencapai target sesuai dengan yang ada dalam deskripsi pekerjaan. Menurut Cascio (2003), Analisa jabatan menggambarkan suatu proses mendapatkan informasi jabatan dimana informasi ini berguna untuk sejumlah tujuan bisnis, termasuk didalamnya informasi tentang tugas yang harus dilakukan pada suatu jabatan, begitu pula informasi tentang karakteristik pribadi yang diperlukan untuk melaksanakan tugas. Menurut Yoder dalam Suwatno (2011) kegunaan lain dari analisa jabatan adalah untuk memastikan adanya keadilan dalam sistem pembayaran gaji antara satu jabatan dengan jabatan lain pada satu perusahaan. Untuk keperluan analisa jabatan diperlukan suatu uraian jabatan yang sangat lengkap.

Tujuan yang ingin dicapai dalam penelitian ini adalah (1) untuk mengetahui seberapa besar pengaruh analisa jabatan, komunikasi organisasi terhadap motivasi secara simultan dan parsial; (2) untuk mengetahui seberapa besar pengaruh analisa jabatan, komunikasi organisasi dan motivasi terhadap kinerja karyawan; berdasarkan pendekatan SPSS vs LISREL. 
Manfaat yang diharapkan dari penelitian ini adalah (1) memberikan masukan kepada perusahaan dari hasil penelitian ini; (2) memberikan tambahan informasi dan dapat memberikan pemahaman mengenai SDM perusahaan; (3) menambah wawasan dan pengetahuan dalam bidang manajemen sumber daya manusia (SDM).

\section{METODE}

Metode yang digunakan dalam penelitian ini adalah (1) jenis penelitian yang digunakan adalah penelitian pengujian hipotesis (kuantitatif); (2) penelitian pengujian hipotesis yang digunakan adalah penelitian (Asosiatif); (3) dimensi waktu penelitian adalah Cross-Sectional; (4) unit analisis adalah individu, yaitu karyawan perusahaan; (5) metode pengambilan sampel adalah populasi, yaitu keseluruhan dari karyawan perusahaan; (6) model empiris berupa analisis jalur (path analysis) dengan bertujuan untuk mengetahui peran langsung maupun tidak langsung seperangkat variabel independen terhadap variabel dependen dengan pendekatan SPSS dan LISREL.

\section{HASIL DAN PEMBAHASAN}

Dalam penelitian ini uji Reliabilitas dan Validitas dilakukan pada masing-masing variabel menggunakan SPSS 16.0, yaitu apabila Cronbach's Alpha> 0,600, maka dinyatakan Reliable sedangkan data dinyatakan valid jika nilai $r_{\text {hitung }}>r_{\text {tabel }}$ Hasil pengujian Reliabilitas pada Tabel 2.

Tabel 2 Uji Reliabilitas

\begin{tabular}{ccc}
\hline Variabel & Cronbach's Alpha & Keterangan \\
\hline Analisa Jabatan $\left(\mathbf{X}_{\mathbf{1}}\right)$ & 0,702 & Reliabel \\
Komunikasi Organisasi $\left(\mathbf{X}_{\mathbf{2}}\right)$ & 0,819 & Reliabel \\
Motivasi (Y) & 0,745 & Reliabel \\
Kinerja Karyawan $(\mathbf{Z})$ & 0,756 & Reliabel \\
\hline
\end{tabular}

Sumber: Hasil Pengolahan Data (2011)

Tabel 3 Uji Validitas

\begin{tabular}{|c|c|c|c|c|}
\hline Variabel & No. Pernyataan & $\begin{array}{c}\text { Corrected Item - Total } \\
\text { Correlation }\end{array}$ & R_Tabel & Keterangan \\
\hline \multirow{4}{*}{$\begin{array}{l}\text { Analisa Jabatan } \\
\qquad\left(\mathbf{X}_{1}\right)\end{array}$} & P1 & 0,430 & 0,31 & Valid \\
\hline & $\mathrm{P} 2$ & 0,539 & 0,31 & Valid \\
\hline & P3 & 0,668 & 0,31 & Valid \\
\hline & P4 & 0,348 & 0,31 & Valid \\
\hline \multirow{5}{*}{$\begin{array}{c}\text { Komunikasi } \\
\text { Organisasi }\left(\mathbf{X}_{\mathbf{2}}\right)\end{array}$} & P5 & 0,657 & 0,310 & Valid \\
\hline & P6 & 0,732 & 0,310 & Valid \\
\hline & P7 & 0,563 & 0,310 & Valid \\
\hline & P8 & 0,606 & 0,310 & Valid \\
\hline & P9 & 0,500 & 0,310 & Valid \\
\hline \multirow{3}{*}{ Motivasi (Y) } & $\mathrm{P} 10$ & 0,452 & 0,31 & Valid \\
\hline & P11 & 0,640 & 0,31 & Valid \\
\hline & $\mathrm{P} 12$ & 0,573 & 0,31 & Valid \\
\hline \multirow{4}{*}{$\begin{array}{c}\text { Kinerja Karyawan } \\
\text { (Z) }\end{array}$} & P13 & 0,509 & 0,31 & Valid \\
\hline & P14 & 0,474 & 0,310 & Valid \\
\hline & P15 & 0,566 & 0,310 & Valid \\
\hline & P16 & 0,735 & 0,310 & Valid \\
\hline
\end{tabular}

Sumber: Hasil Pengolahan Data (2011) 
Tabel 4 Nilai Baru Setelah Transformasi dari Ordinal Ke Interval

\begin{tabular}{cc}
\hline Opsi dari Jawaban (Ordinal) & Nilai Baru (Interval) \\
\hline $\mathbf{1}$ & 1 \\
$\mathbf{2}$ & 1,972 \\
$\mathbf{3}$ & 2.912 \\
$\mathbf{4}$ & 3,613 \\
\hline Sumber : Hasil Pengolahan Data (2011)
\end{tabular}

Analisi korelasi dilakukan untuk mengetahui hubungan antara variabel. Perhitungan koefisien korelasi dilakukan dengan menggunakan program SPSS 16.0. dimana jika nilai probabilitas 0.05 lebih besar atau sama dengan nilai probabilitas sig atau $[0.05 \geq S i g]$, maka huhungan signifikan dan hasil pengolahan korelasi seperti pada Tabel 5.

Tabel 5 Sifat hubungan $\mathrm{X}_{1}, \mathrm{X}_{2}, \mathrm{Y}$ dan $\mathrm{Z}$

\begin{tabular}{ccc}
\hline Variabel & Korelasi & Sifat Hubungan \\
\hline $\mathbf{X}_{\mathbf{1}}$ terhadap $\mathbf{Y}$ & 0.628 & Kuat, searah dan signifikan \\
$\mathbf{X}_{\mathbf{2}}$ terhadap $\mathbf{Y}$ & 0.546 & Cukup kuat, searah dan signifikan \\
$\mathbf{X}_{\mathbf{1}}$ terhadap $\mathbf{Z}$ & 0.665 & Kuat, searah dan signifikan \\
$\mathbf{X}_{\mathbf{2}}$ terhadap $\mathbf{Z}$ & 0.599 & Cukup kuat, searah dan signifikan \\
$\mathbf{Y}$ terhadap $\mathbf{Z}$ & 0.772 & Kuat, searah dan signifikan \\
\hline
\end{tabular}

Sumber : Hasil Pengolahan Data (2011)

Dilanjutkan dengan metode analisis jalur (Path Analysis) dengan pendekatan SPSS. Langkah pengujian analisis jalur ini dibagi menjadi dua, dimana pengujian dilakukan secara keseluruhan dan individu untuk 2 struktur yang dipecah menjadi sub - struktur 1 dan sub - struktur 2. Berikut ini merupakan kerangan hubungan antara jalur $\left(\mathrm{X}_{1}, \mathrm{X}_{2}\right.$ dan $\mathrm{Y}$ terhadap $\left.\mathrm{Z}\right)$ dan dibuat dalam persamaan structural sebagai berikut ini, yaitu:

$$
\begin{array}{ll}
\mathbf{Y}=\boldsymbol{\rho}_{\mathrm{yx} 1} \mathbf{X}_{1}+\boldsymbol{\rho}_{\mathrm{yx} 2} \mathbf{X}_{2}+\rho_{\mathrm{y}} \boldsymbol{\varepsilon}_{1} & \text { (Persamaan Sub-Struktural 1) } \\
\mathbf{Z}=\boldsymbol{\rho}_{\mathrm{zx} 1} \mathbf{X}_{1}+\boldsymbol{\rho}_{\mathrm{zx} 2} \mathbf{X}_{\mathbf{2}}+\boldsymbol{\rho}_{\mathrm{zy}} \mathbf{Y}+\boldsymbol{\rho}_{\mathrm{z}} \boldsymbol{\varepsilon}_{\mathbf{2}} & \text { (persamaan sub-struktural 2) }
\end{array}
$$

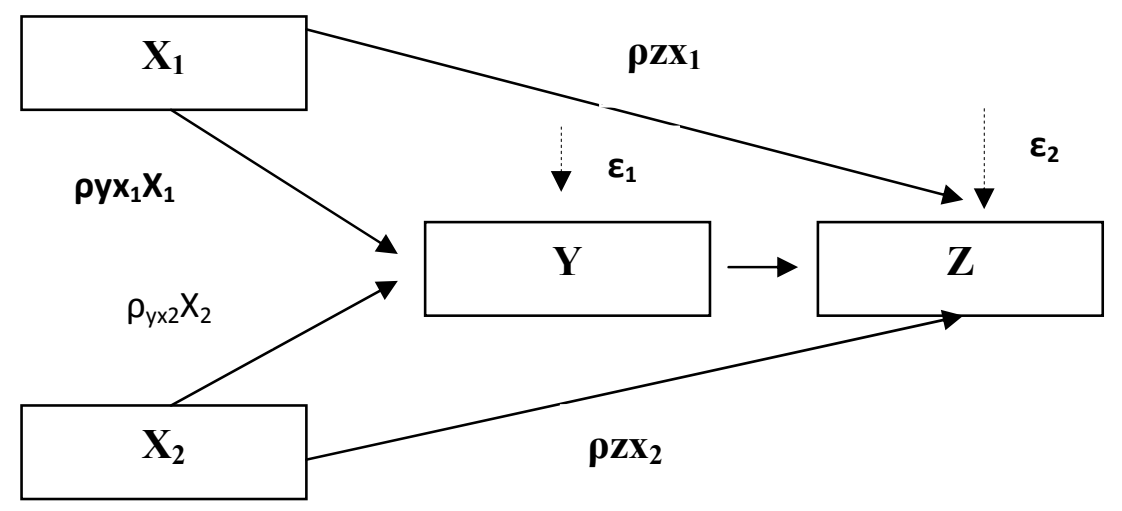

Gambar 1 Struktur Pengaruh X1, X2, Y dan Z

Sumber : Diolah penulis (2011) 


\section{Pengujian Sub-Struktural 1}

\section{Pengujian Secara Simultan (Keseluruhan)}

Tabel 6 Model Summary Sub-Struktur 1

\begin{tabular}{|c|c|c|c|c|}
\hline \multicolumn{5}{|c|}{ Model Summary } \\
\hline Model & $\mathrm{R}$ & R Square & Adjusted R Square & $\begin{array}{l}\text { Std. Error of the } \\
\text { Estimate }\end{array}$ \\
\hline 1 & $.738^{a}$ & .544 & .519 & .43196 \\
\hline
\end{tabular}

Diketahui bahwa variable Analisa Jabatan $\left(\mathrm{X}_{1}\right)$ dan Komunikasi Organisasi $\left(\mathrm{X}_{2}\right)$ terhadap Motivasi (Y) sebesar R Square $\left(\mathrm{R}^{2}\right)$ adalah $0.544=54.4 \%$ dan besarnya pengaruh variabel lain yang mempengaruhi variabel Motivasi (Y) diluar penelitian ini adalah sebesar 45.6\%. Sementara itu, besarnya koefisien jalur bagi variabel lain diluar penelitian yang mempengaruhi dapat dihitung melalui rumus sebagai berikut:

$$
\begin{aligned}
\rho_{\mathrm{y}} \varepsilon_{1} & =\sqrt{1-\mathrm{R}^{2} \mathrm{xy}} \\
& =1-0,544 \\
& =0,675
\end{aligned}
$$

Tabel 7 Anova Sub-Struktur 1

ANOVA $^{\mathrm{b}}$

\begin{tabular}{|ll|r|r|r|r|r|}
\hline Model & Sum of Squares & df & Mean Square & F & Sig. \\
\hline 1 & Regression & 8.236 & 2 & 4.118 & 22.070 & $.000^{a}$ \\
& Residual & 6.904 & 37 & .187 & & \\
& Total & 15.140 & 39 & & & \\
\hline
\end{tabular}

b. Dependent Variable: $Y$

Sumber : Hasil Pengolahan Data (2011)

Dari hasil uji Signifikan pada Tabel 7. Anova Sub-struktur 1, diperoleh sig sebesar 0.000. Jika dibandingkan dengan $\alpha=0.05$, maka siglebih kecil dari $\boldsymbol{\alpha}(\operatorname{Sig} \leq \alpha)$ yaitu $0.000 \leq 0.05$ yang artinya Ho ditolak dan Ha diterima, yang menunjukkan bahwa ada pengaruh atau kontribusi antara variabel Analisa Jabatan dan variabel Komunikasi Organisasi secara simultan dan signifikan terhadap variabel Motivasi. 


\section{Pengujian Secara Individu}

Tabel 8 Coefficient Sub-Struktur 1

\begin{tabular}{|c|c|c|c|c|c|c|}
\hline \multicolumn{7}{|c|}{ Coefficients $^{a}$} \\
\hline \multirow{2}{*}{\multicolumn{2}{|c|}{ Model }} & \multicolumn{2}{|c|}{ Unstandardized Coefficients } & \multirow{2}{*}{$\begin{array}{c}\text { Standardized } \\
\text { Coefficients } \\
\text { Beta }\end{array}$} & \multirow[b]{2}{*}{$\mathrm{t}$} & \multirow[b]{2}{*}{ Sig. } \\
\hline & & B & Std. Error & & & \\
\hline \multirow[t]{3}{*}{1} & (Constant) & .465 & .355 & & 1.309 & .199 \\
\hline & $\mathrm{X} 1$ & .349 & .078 & .516 & 4.468 & .000 \\
\hline & $\mathrm{x} 2$ & .458 & .132 & .402 & 3.478 & .001 \\
\hline
\end{tabular}

Sumber : Hasil Pengolahan Data,2011

\section{Pengujian secara individu antara $X_{1}$ dan $Y$}

Hipotesisnya, yaitu:

Ho: Variabel Analisa Jabatan $\left(\mathrm{X}_{1}\right)$ tidak berpengaruh secara individu terhadap varibel Motivasi $(\mathrm{Y})$ Ha: Variabel Analisa Jabatan $\left(\mathrm{X}_{1}\right)$ berpengaruh secara individu terhadap variabel Motivasi $(\mathrm{Y})$

Dasar pengambilan keputusan yaitu dalam Uji t dan Uji Sig. Uji t adalah jika:

$t_{\text {hitung }}<t_{\text {tabel }}$ : Ho diterima ( Ha ditolak )

$t_{\text {hitung }}>t_{\text {tabel }}:$ Ha diterima ( Ho ditolak )

Uji Sig adalah: 1) jika nilai probabilitas lebih kecil atau sama dengan nilai probabilitas Sig atau $(0.05 \leq \mathrm{Sig})$, maka Ho diterima dan Ha ditolak, artinya tidak signifikan; 2) jika nilai probabilitas lebih besar atau sama dengan nilai probabilitas Sig atau $(0.05 \geq \mathrm{Sig})$, maka Ho ditolak dan Ha diterima, artinya signifikan.

Nilai $t_{\text {tabel }}$ dilihat pada taraf signifikan 0.05 di mana $\mathrm{df}=$ jumlah sampel - jumlah variabel $=40$

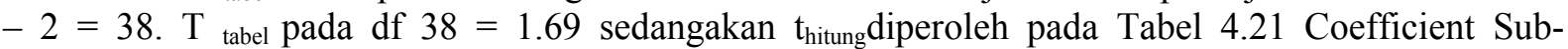

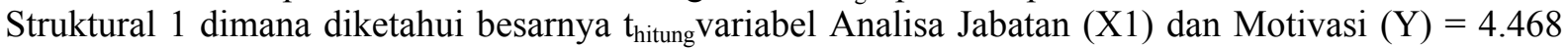
yang berarti $t_{\text {hitung }}>\mathrm{t}_{\text {tabel }}(4.468>1.69)$, maka Ho ditolak dan Ha diterima artinya variabel Analisa Jabatan (X1) berpengaruh secara individu terhadap variabel Motivasi (Y). Dari Tabel 1.8 Coefficient Sub-Struktural 1, diketahui bahwa variabel Analisa Jabatan (X1) mempunyai nilai Sig. Sebesar 0.000, jika dibandingkan dengan $\alpha=0.05$, nilai sig. lebih kecil dari pada nilai $\alpha(0.000<0.05)$, maka Ho ditolak dan Ha Diterima, artinya signifikan dan besarnya Beta (koefisien jalur) variabel Analisa Jabatan (X1) terhadap variabel Motivasi (Y) adalah 0,516 ( $\rho$ YX1).

\section{Pengujian secara individu antara $X_{2}$ dan $Y$}

Hipotesisnya yaitu:

Ho : Variabel Komunikasi Organisasi (X2) tidak berpengaruh secara individu terhadap variabel Motivasi (Y)

Ha : Variabel Komunikasi Organisasi (X2) berpengaruh secara individu terhadap variabel Motivasi (Y)

Dasar pengambilan keputusan berupa Uji t dan Uji Sig. Uji t adalah jika:

$t_{\text {hitung }}<t_{\text {tabel }}$ : Ho diterima ( Ha ditolak )

$t_{\text {hitung }}>t_{\text {tabel }}:$ Ha diterima ( Ho ditolak ) 
Uji Sig adalah: (1) jika nilai probabilitas lebih kecil atau sama dengan nilai probabilitas Sig atau $(0.05 \leq \mathrm{Sig})$, maka Ho diterima dan Ha ditolak, artinya tidak signifikan; dan (2) Jika nilai probabilitas lebih besar atau sama dengan nilai probabilitas Sig atau ( $0.05 \geq \mathrm{Sig})$, maka Ho ditolak dan Ha diterima, artinya signifikan.

Nilai $t_{\text {tabel }}$ dilihat pada taraf signifikan 0.05 dimana $\mathrm{df}=$ jumlah sampel - jumlah variabel $=40$ $-2=38 . \mathrm{T}_{\text {tabel }}$ pada df $38=1.69$ sedangakn $\mathrm{T}$ hitung diperoleh pada Tabel 4.21 Coefficient SubStruktural 1 dimana diketahui besarnya $t_{\text {hitung }}$ variabel Komunikasi Organisasi (X2) dan Motivasi (Y)= 3,478 yang berarti $t_{\text {hitung }}>t$ tabel $(3,478>1.69)$, maka Ho ditolak dan Ha diterima artinya variabel Komunikasi Organisasi (X2) berpengaruh secara individu terhadap variabel Motivasi (Y). Dari Tabel 1.8 Coefficient Sub-Struktural 1, diketahui bahwa variabel Komunikasi Organisasi (X2) mempunyai nilai Sig. Sebesar 0.001. jika dibandingkan dengan $\alpha=0.05$, nilai sig. Lebih kecil dari pada nilai $\alpha$ ( $0.001<0.05$ ), maka Ho ditolak dan Ha Diterima, artinya signifikan dan besarnya Beta (koefisien jalur) variabel Komunikasi Organisasi (X2) terhadap variabel Motivasi (Y) adalah $0.402(\rho Y X 2)$.

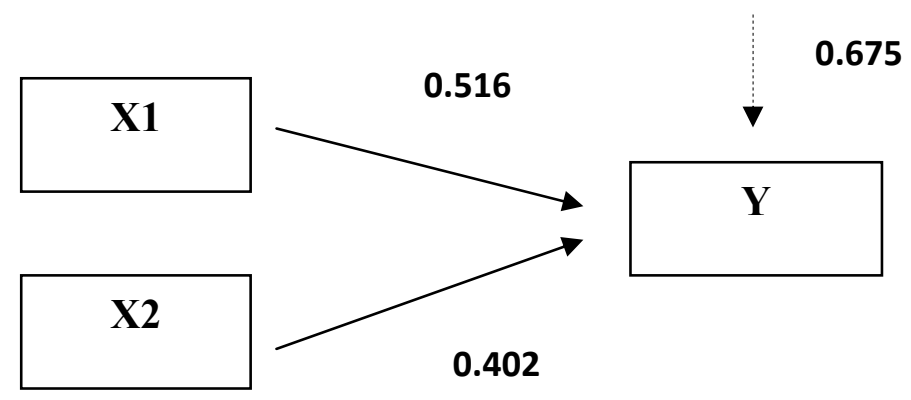

Gambar 2 Sub-Struktur 1

Sumber: Hasil Pengolahan Data (2011)

Dari pengujian tersebut, maka diperoleh persamaan sub-struktural 1 sebagai berikut:

$\mathrm{Y}=\rho_{\mathrm{yx} 1} \mathrm{X}_{1}+\rho_{\mathrm{yx} 2} \mathrm{X}_{2}+\rho_{\mathrm{y}} \varepsilon_{1}$

$\mathrm{Y}=00.516 \mathrm{X}_{1}+0.402 \mathrm{X}_{2}+0.675 \varepsilon_{1}$

\section{Pengujian Sub-Struktural 2}

\section{Pengujian secara simultan (Keseluruhan)}

Tabel 9 Model Summary Sub-Struktural 2

\begin{tabular}{|l|r|r|r|c|}
\hline \multicolumn{5}{|c|}{ Model Summary $^{\text {b }}$} \\
\hline Model & $\mathrm{R}$ & R Square & \multicolumn{1}{c|}{$\begin{array}{c}\text { Adjusted R } \\
\text { Square }\end{array}$} & $\begin{array}{l}\text { Std. Error of the } \\
\text { Estimate }\end{array}$ \\
\hline 1 & $.840^{\mathrm{a}}$ & .705 & .681 & .38527 \\
\hline
\end{tabular}

a. Predictors: (Constant), Y, X2, X1

b. Dependent Variable: Z

Sumber : Hasil Pengolahan Data (2011) 
Besarnya pengaruh variabel $\mathrm{X}_{1}, \mathrm{X}_{2}$ dan $\mathrm{Y}$ secara simultan terhadap $\mathrm{Z}$ dapat diketahui dengan melihat nilai $R$ Square pada Tabel 9. bahwa $R$ Square $\left(\mathrm{R}^{2}\right)$ adalah $0.705=70.5 \%$ dan besarnya pengaruh variabel lain yang mempengaruhi variabel Kinerja Karyawan (Y) diluar penelitian ini adalah sebesar 29,5\%.Sementara itu, besarnya koefisien jalur bagi variabel lain diluar penelitian yang mempengaruhi dapat dihitung melalui rumus:

$$
\begin{aligned}
\rho_{\mathrm{y}} \varepsilon_{1} & =\sqrt{1-\mathrm{R}^{2} \mathrm{xy}} \\
& =\sqrt{1-0.705} \\
& =0.543
\end{aligned}
$$

\begin{tabular}{|c|c|c|c|c|c|c|}
\hline \multicolumn{7}{|c|}{ ANOVA $^{b}$} \\
\hline \multicolumn{2}{|c|}{ Model } & $\begin{array}{l}\text { Sum of } \\
\text { Squares }\end{array}$ & $\mathrm{df}$ & Mean Square & $\mathrm{F}$ & Sig. \\
\hline \multirow[t]{3}{*}{1} & Regression & 12.794 & 3 & 4.265 & 28.730 & $.000^{\mathrm{a}}$ \\
\hline & Residual & 5.344 & 36 & .148 & & \\
\hline & Total & 18.137 & 39 & & & \\
\hline
\end{tabular}

Tabel 10 Anova Sub-Struktur 2

Sumber : Hasil Pengolahan Data (2011)

Dari hasil uji Signifikan pada Tabel 10. Anova Sub-struktur 2, diperoleh sig sebesar 0.000. Jika dibandingkan dengan $\alpha=0.05$, maka siglebih kecil dari $\alpha$ ( Sig $\leq \alpha)$ yaitu $0.000 \leq 0.05$ yang artinya Ho ditolak dan Ha diterima, yang menunjukkan bahwa ada pengaruh atau kontribusi antara variabel Analisa Jabatan, variabel Komunikasi Organisasi dan variabel Motivasi secara simultan dan signifikan terhadap variabel Kinerja Karyawan.

\section{Pengujian secara individu}

Tabel 11 Coefficient Sub-Struktur 2

\begin{tabular}{|c|c|c|c|c|c|c|}
\hline \multirow{2}{*}{\multicolumn{2}{|c|}{ Model }} & \multicolumn{2}{|c|}{ Unstandardized Coefficients } & \multirow{2}{*}{$\begin{array}{c}\begin{array}{c}\text { Standardized } \\
\text { Coefficients }\end{array} \\
\text { Beta }\end{array}$} & \multirow[b]{2}{*}{$\mathrm{t}$} & \multirow[b]{2}{*}{ Sig. } \\
\hline & & B & Std. Error & & & \\
\hline \multirow[t]{4}{*}{1} & (Constant) & -.130 & .324 & & -.402 & .690 \\
\hline & $x 1$ & .242 & .086 & .328 & 2.803 & .008 \\
\hline & $\mathrm{x} 2$ & .353 & .135 & .283 & 2.610 & .013 \\
\hline & Y & .451 & .147 & .412 & 3.073 & .004 \\
\hline
\end{tabular}
Coefficients $^{\mathrm{a}}$ 


\section{Pengujian secara individu antara $X_{1}$ dan $Z$}

Hipotesisnya yaitu:

Ho : Variabel Analisa Jabatan (X1) tidak berpengaruh secara individu terhadap varibel Kinerja Karyawan (Z)

Ha : Variabel Analisa Jabatan (X1) berpengaruh secara individu terhadap varibel Kinerja Karyawan $(\mathrm{Z})$

Dasar pengambilan keputusan berupa Uji t dan Uji Sig. Uji t, jika:

$t_{\text {hitung }}<t_{\text {tabel }}:$ Ho diterima ( Ha ditolak )

$t_{\text {hitung }}>t_{\text {tabel }}:$ Ha diterima ( Ho ditolak )

Uji Sig, yaitu: (1) jika nilai probabilitas lebih kecil atau sama dengan nilai probabilitas Sig atau $(0.05 \leq \mathrm{Sig})$, maka Ho diterima dan Ha ditolak, artinya tidak signifikan; dan (2) jika nilai probabilitas lebih besar atau sama dengan nilai probabilitas Sig atau (0.05 $\geq$ Sig), maka Ho ditolak dan Ha diterima, artinya signifikan.

Nilai $t_{\text {tabel }}$ dilihat pada taraf signifikan 0.05 dimana $\mathrm{df}=$ jumlah sampel - jumlah variabel $=40$ $-2=38 . \mathrm{T}$ tabel pada df $38=1.69$ sedangakn $\mathrm{T}$ hitung diperoleh pada Tabel 4.24 Coefficient Sub-

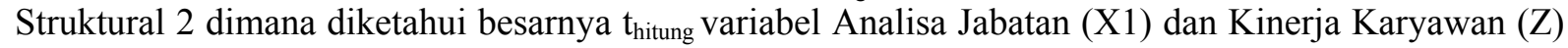
$=2.803$ yang berarti $t_{\text {hitung }}>t$ table $(2.803>1.69)$, maka Ho ditolak dan Ha diterima artinya variabel Analisa Jabatan (X1) berpengaruh secara individu terhadap variabel Kinerja karyawan (Z).diketahui bahwa variabel Analisa Jabatan (X1) mempunyai nilai Sig. Sebesar 0.008. jika dibandingkan dengan $\alpha$ $=0.05$, nilai sig. Lebih kecil dari pada nilai $\boldsymbol{\alpha}(0.008<0.05)$, maka Ho ditolak dan Ha Diterima, artinya signifikan dan besarnya Beta (koefisien jalur) variabel Analisa Jabatan (X1) terhadap variabel Kinerja Karyawan $(\mathrm{Z})$ adalah $0.328(\rho \mathrm{ZX} 1)$.

\section{Pengujian secara individu antara $X_{2}$ dan $Z$}

Hipotesisnya yaitu:

Ho : Variabel Komunikasi Organisasi (X2) tidak berpengaruh secara individu terhadap variabel Kinerja Karyawan (Z)

Ha : VariabelKomunikasi Organisasi (X2) berpengaruh secara individu terhadap variabel Kinerja Karyawan $(\mathrm{Z})$

Dasar pengambilan keputusan berupa Uji t dan Uji Sig. Uji t yaitu:

$t_{\text {hitung }}<t_{\text {tabel }}:$ Ho diterima ( Ha ditolak )

$t_{\text {hitung }}>t_{\text {tabel }}:$ Ha diterima ( Ho ditolak )

Uji Sig: 1) Jika nilai probabilitas lebih kecil atau sama dengan nilai probabilitas Sig atau (0.05 $\leq$ Sig), maka Ho diterima dan Ha ditolak, artinya tidak signifikan. 2) Jika nilai probabilitas lebih besar atau sama dengan nilai probabilitas Sig atau $(0.05 \geq$ Sig), maka Ho ditolak dan Ha diterima, artinya signifikan.

Nilai $t_{\text {tabel }}$ dilihat pada taraf signifikan 0.05 dimana $\mathrm{df}=$ jumlah sampel - jumlah variabel $=40$ $-2=38 . \mathrm{T}$ tabel pada df $38=1.69$ sedangakn $\mathrm{T}$ hitung diperoleh pada Tabel 4.24 Coefficient SubStruktural 2 dimana diketahui besarnya $\mathrm{t}_{\text {hitung }}$ variabel Komunikasi Oganisasi (X2) dan Kinerja Karyawan $(Z)=2.610$ yang berarti $t_{\text {hitung }}>t$ tabel $(2.610>1.69)$, maka Ho ditolak dan Ha diterima artinya variabel Komunikasi Organisasi (X2) berpengaruh secara individu terhadap variabel Kinerja Karyawan (Z).Diketahui bahwa variabel Komunikasi Organisasi (X2) mempunyai nilai Sig. Sebesar 0.013. jika dibandingkan dengan $\alpha=0.05$, nilai sig. Lebih kecil dari pada nilai $\alpha(0.013<0.05)$, maka Ho ditolak dan Ha Diterima, artinya signifikan dan besarnya Beta (koefisien jalur) variabel Gaya Kepemimpinan (X2) terhadap variabel Kinerja Karyawan (Z) adalah 2.83 ( $\rho Z X 2)$. 


\section{Pengujian secara individu antara $Y$ dan $Z$}

Hipotesisnya yaitu:

Ho : Variabel Motivasi (Y) tidak berpengaruh secara individu terhadap variabel Kinerja Karyawan (Z) Ha : Variabel Motivasi (Y) berpengaruh secara individu terhadap variabel Kinerja Karyawan (Z)

Dasar pengambilan keputusan berupa Uji t dan Uji Sig. Uji t yaitu:

$t_{\text {hitung }}<t_{\text {tabel }}:$ Ho diterima ( Ha ditolak )

$t_{\text {hitung }}>t_{\text {tabel }}:$ Ha diterima ( Ho ditolak )

Uji Sig, yaitu: (1) jika nilai probabilitas lebih kecil atau sama dengan nilai probabilitas Sig atau $(0.05 \leq \mathrm{Sig})$, maka Ho diterima dan Ha ditolak, artinya tidak signifikan; (2) Jika nilai probabilitas lebih besar atau sama dengan nilai probabilitas Sig atau $(0.05 \geq \mathrm{Sig})$, maka Ho ditolak dan Ha diterima, artinya signifikan.

Nilai $t_{\text {tabel }}$ dilihat pada taraf signifikan 0.05 dimana $\mathrm{df}=$ jumlah sampel - jumlah variabel $=40$ $-2=38 . \mathrm{T}$ tabel pada df $38=1.69$ sedangakn $\mathrm{T}$ hitung diperoleh pada Tabel 4.24 Coefficient SubStruktural 2 dimana diketahui besarnya $t_{\text {hitung }}$ variabel Motivasi $(\mathrm{Y})$ dan Kinerja Karyawan $(\mathrm{Z})=3.073$ yang berarti thitung $>\mathrm{t}_{\text {tabel }}(3.073>1.69)$, maka Ho ditolak dan Ha diterima artinya variabel Motivasi (Y) berpengaruh secara individu terhadap variabel Kinerja Karyawan (Z). Diketahui bahwa variabel Kepuasan Kerja (Y) mempunyai nilai Sig. Sebesar 0.004. jika dibandingkan dengan $\alpha=0.05$, nilai sig. Lebih kecil dari pada nilai $\alpha(0.004<0.05)$, maka Ho ditolak dan Ha Diterima, artinya signifikan dan besarnya Beta (koefisien jalur) variabel Motivasi (Y) terhadap variabel Kinerja Karyawan (Z) adalah $0.412(\rho Z Y)$.



Gambar 3 Sub-Struktur 2

Sumber : Hasil Pengolahan Data (2011)

Dari pengujian tersebut, maka diperoleh persamaan sub-struktural 2 sebagai berikut:

$$
\begin{aligned}
& Z=\rho_{\mathrm{zx} 1} X_{1}+\rho_{\mathrm{zx} 2} X_{2}+\rho_{z y} Y+\rho_{z} \varepsilon_{2} \\
& Z=0.328 X_{1}+0.283 X_{2}+0.412 Y+0.543 \varepsilon_{2}
\end{aligned}
$$


Dilanjutkan dengan metode analisis jalur (Path Analysis) dengan pendekatan LISREL.

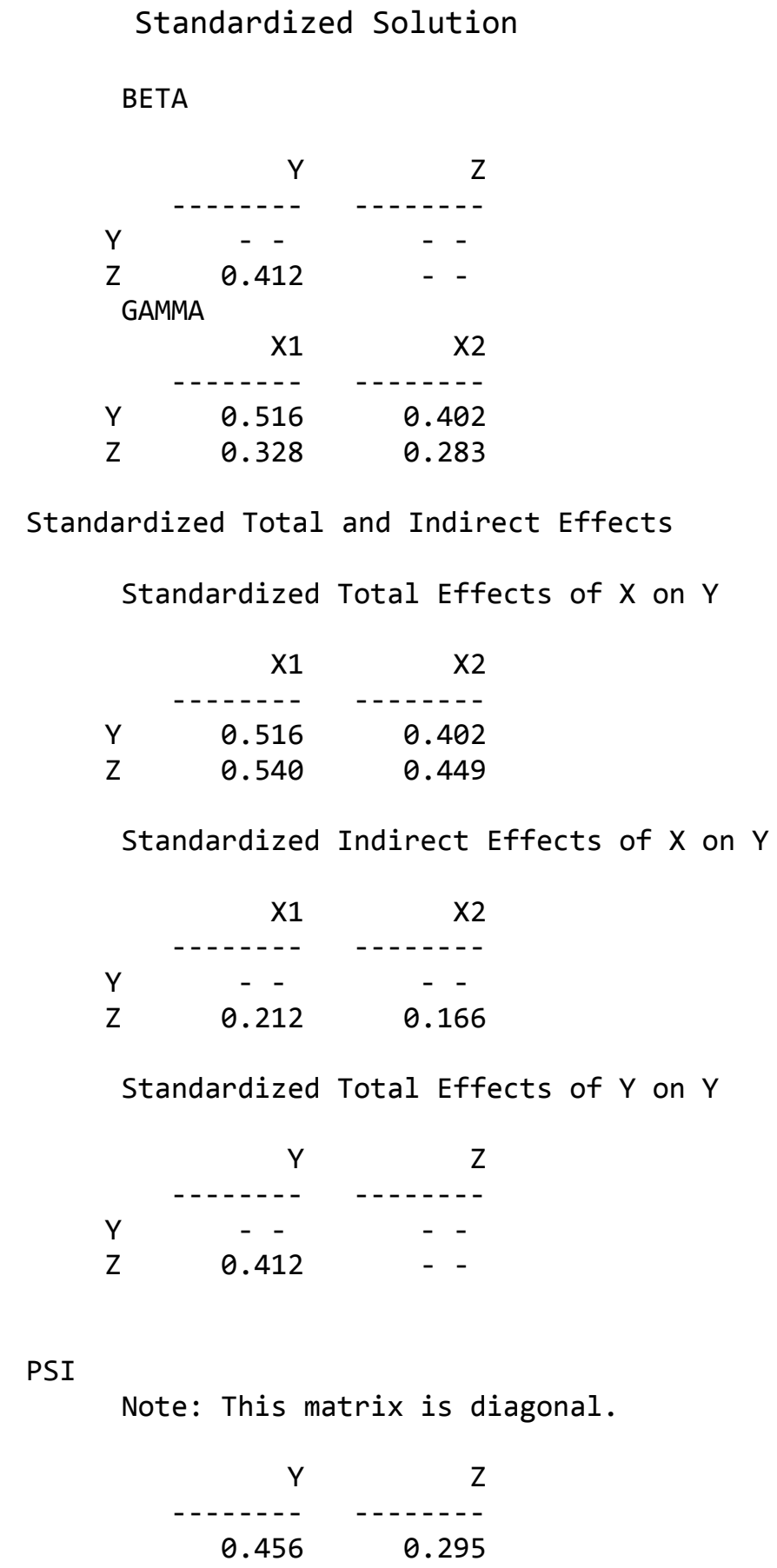

Berdasarkan matriks BETA, dapat diketahui bahwa besarnya pengaruh antaravariabel Motivasi (Y) dan Kinerja Karyawan (Z) adalah sebesar 0.412 atau berkontribusi sebesar 16.97\%.

Berdasarkan matriks GAMMA, dapat diketahui besarnya pengaruh antara variabel Analisa Jabatan $\left(\mathrm{X}_{1}\right)$ dan variabel Motivasi $(\mathrm{Y})$ adalah sebesar 0.516 atau berkontribusi sebesar $26.62 \%$ dan Besarnya koefisien jalur antara variabel Analisa Jabatan $\left(\mathrm{X}_{1}\right)$ dan variabel Kinerja Karyawan $(\mathrm{Z})$ secara langsung adalah sebesar 0.328 atau berkontribusi sebesar $10.76 \%$. sedangkan pengaruh antara 
Komunikasi Organisasi $\left(\mathrm{X}_{2}\right)$ dan variabel Motivasi (Y) adalah sebesar 0.402 atau berkontribusi sebesar $16.16 \%$ dan besarnya koefisen jalur antara variabel Komunikasi Organisasi $\left(\mathrm{X}_{2}\right)$ dan variabel Kinerja Karyawan (Z) secara langsung adalah 0.283 atau berkontribusi sebesar $8 \%$.

Berdasarkan matriks Standarized indirectof $\mathrm{X}$ on $\mathrm{Y}$, dapat diketahui besarnya pengaruh antara variabel Analisa Jabatan $\left(\mathrm{X}_{1}\right)$ dan variabel Kinerja Karyawan $(\mathrm{Z})$ secara tidak langsung adalah sebesar 0.212 atau berkontribusi sebesar $4.49 \%$ dan variabel Komuikasi Organisasi $\left(\mathrm{X}_{2}\right)$ dan Variabel Kinerja Karyawan (Z) secara tidak langsung adalah sebesar 0.166 atau berkontribusi sebesar $2.75 \%$.

Berdasarkan matriks Total Effects of $\mathrm{X}$ on $\mathrm{Y}$, dapat diketahui besarnya koefisien jalur antara Analisa Jabatan (X1) dan Kinerja Karyawan (Z) secara total yaitu sebesar 0.540 atau kontribusi sebesar 29.16\%, sementara Komunikasi Organisasi (X2) dan Kinerja Karyawan (Z) secara total yaitu sebesar 0.449 atau kontribusi sebesar $20.16 \%$.

Berdasarkan matriks PSI dapat diketahui bahwa besarnya pengaruh dari variabel lain yang mempengaruhi nilai $\mathrm{Y}$ adalah sebesar 0.456 . besarnya koefisien jalur dari variabel lain yang mempengaruhi nilai variabel $\mathrm{Y}\left(\varepsilon_{\mathrm{y}}\right)=\sqrt{0.456}=0.675$. selain itu diketahui pula bahwa besarnya pengaruh dari variabel lain yang mempengaruhi nilai $Z$ adalah sebesar 0.295 , sedangkan besarnya koefisien jalur dari variabel lain mempengaruhi nilai $Z\left(\varepsilon_{z}\right)=\sqrt{0.295}=0.543$.

Dengan ini berarti analisa telah selesai, maka dapat digambarkan struktur hubungan secara lengkap, yakni $\mathrm{X}_{1}, \mathrm{X}_{2}, \mathrm{Y}$, dan $\mathrm{Z}$ yang memiliki persamaan stuktural :

$\mathrm{Y}=0.516 \mathrm{X}_{1}+0.402 \mathrm{X}_{2}+0.675 \varepsilon_{1}$

$\mathrm{Z}=0.328 \mathrm{X}_{1}+0.283 \mathrm{X}_{2}+0.412 \mathrm{Y}+0.543 \varepsilon_{2}$



Gambar 4 Struktur Pengaruh $\mathrm{X}_{1}, \mathrm{X}_{2}, \mathrm{Y}$ dan $\mathrm{Z}$

Berdasarkan hasil penelitian, berikut ini akan dikemukan beberapa implikasi antara lain: (1) pengolahan dan analisis data berdasarkan perbandingan pendekatan SPSS dan LISREL menunjukkan hasil yang sama, bahwa terdapat hubungan yang kuat antara analisa jabatan dengan motivasi karyawan yaitu sebesar 0.628 dan memiliki pengaruh yang signifikan yaitu 0.516 atau sebesar $26.63 \%$; (2) Pengolahan dan analisis data berdasarkan perbandingan pendekatan SPSS dan LISREL menunjukkan hasil yang sama, bahwa terdapat hubungan yang cukup kuat yaitu sebesar 0.546 dan pengaruh yang signifikan yaitu 0.402 atau sebesar $16.16 \%$; (3) Pengolahan dan analisis data berdasarkan perbandingan pendekatan SPSS dan LISREL menunjukkan hasil yang sama, bahwa terdapat hubungan yang kuat yaitu sebesar 0.665 dan pengaruh yang signifikan yaitu 0.328 atau sebesar $10.76 \%$ antara analisa jabatan terhadap kinerja karyawan; (4) Pengolahan dan analisis data berdasarkan perbandingan 
pendekatan SPSS dan LISREL menunjukkan hasil yang sama, bahwa terdapat hubungan yang cukup kuat yaitu sebesar 0.599 dan pengaruh yang signifikan yaitu 0.283 atau sebesar $8 \%$ antara komunikasi organisasi terhadap kinerja karyawan; dan (5) Pengolahan dan analisis data berdasarkan perbandingan pendekatan SPSS dan LISREL menunjukkan hasil yang sama, bahwa terdapat hubungan yang kuat yaitu sebesar 0.772 dan pengaruh yang signifikan yaitu 0.412 atau sebesar $16.97 \%$ antara motivasi terhadap kinerja karyawan.

\section{PENUTUP}

Berdasarkan pembahasan dan hasil penelitian mengenai pengaruh Analisa Jabatan dan Komunikasi Organisasi terhadap Motivasi dan dampaknya pada Kinerja Karyawan perusahaan, maka diambil simpulan, bahwa hasil analisis menunjukan bahwa setiap variabel yang diteliti memiliki pengaruh yang signifikan.

\section{DAFTAR PUSTAKA}

Cascio, W. (2003). Personnel management. New York: Prentice Hall.

Suwatno, \& Priansa, D. J. (2011). Manajemen SDM dalam organisasi publik dan bisnis. Bandung: Alfabeta. 